
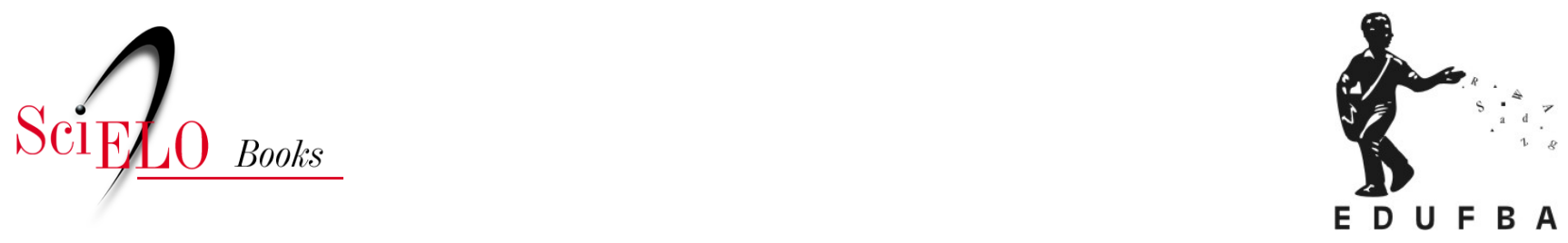

\title{
Reflexões \\ Por uma política de divulgação científica
}

\author{
Nelson De Luca Pretto
}

PRETTO, N.D.L. Por uma política de divulgação científica. In: Educações, culturas e hackers: escritos e reflexões [online]. Salvador: EDUFBA, 2017, pp. 155-156. ISBN: 978-85-232-2019-8.

https://doi.org/10.7476/9788523220198.0037.

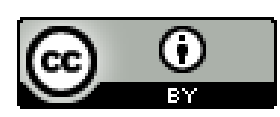

All the contents of this work, except where otherwise noted, is licensed under a Creative Commons Attribution $\underline{4.0 \text { International license. }}$

Todo o conteúdo deste trabalho, exceto quando houver ressalva, é publicado sob a licença Creative Commons Atribição 4.0. 


\section{Por uma política de divulgação científica}

"A pobreza da Bahia não é só econômica, mas de empreendedores de talento", afirmou Paulo Ormindo, em artigo no jornal $A$ Tarde, de $1^{\circ}$ de março de 2015. Perfeito diagnóstico e quase prognóstico feito por ele, descrevendo a tristeza de nossa elite empresarial (e política) que nem mesmo se utiliza das tais responsabilidades sociais para investir na transformação da Bahia num rico espaço para se viver. Parece que a Bahia não interessa, o que interessa é possuir "uma Mercedes e uma lancha seminova” (Paulo Ormindo) e pensar no lá fora; melhor ainda se esse lá fora for do outro lado do Atlântico, como, aliás, era assim o pensamento das oligarquias no nosso passado colonial. Pouco se investe na conservação dos patrimônios baiano e nacional, fundamentais para o conhecimento do nosso passado, para a construção da memória e do futuro. Paulo Ormindo mencionou a situação de alguns engenhos que poderiam, se restaurados, consolidar-se como uma Envolvente dos Engenhos, Capoeira e Samba de Roda do Recôncavo. Esse patrimônio está sendo consumido, como, aliás, pudemos constatar com igual tristeza e indignação, na mesma edição de $A$ Tarde, em matéria sobre o fechamento do Museu do Vaqueiro, em Santa Rosa de Lima, município de Jaguarari; este museu, a bem da verdade, só foi criado e se mantinha por uma verdadeira obstinação do jovem Danilo Rodrigues da Silva, que saiu coletando materiais e assim pode constituí-lo.

Exemplos não nos faltariam, mas quero voltar aqui ao meu mantra, que é o Museu de Ciência e Tecnologia de Pituaçu, sofredor pela mesma irresponsável destruição. A SBPC tem insistido, por todos os meios, na necessária intervenção do governador Rui Costa para uma breve solução para tamanho descaso. Tivemos audiência com o novo secretário de Ciência, Tecnologia e Inovação para apresentar-lhe a nossa indignação, cobrando uma posição de governo sobre a questão. A Universidade Estadual da Bahia (UNEB), instituição pública de ensino e pesquisa que dele cuidava, simplesmente ocupa o seu espaço - o primeiro prédio na Amé- 
rica Latina construído exclusivamente para ser um museu de C\&T - com instâncias administrativas. Recentemente, estivemos reunidos, SBPC e Academia de Ciências da Bahia, presidida por Roberto Santos, governador à época da criação do Museu, para darmos andamento à nossa peregrinação em defesa do Museu de Pituaçu e na luta pela construção de mais museus na Bahia. Essa ação teria que integrar uma política de divulgação científica, incluindo uma forte atuação midiática, visando dar visibilidade, local e nacional, para o que se produz no estado. Temos carência de uma clara política de C\&T para a Bahia. Precisamos recuperar esse tempo: pois um Estado e uma nação que pensam em ser educadores, precisam investir forte na formação científica da sua juventude. Essa formação se faz com escolas, obviamente, mas tem que ir muito além. Um museu contemporâneo é o espaço da memória e também espaço da cultura e da criação. Ali na Boca do Rio, bairro adensado de Salvador, no rico Parque de Pituaçu, pode-se pensar em ocupar o prédio com equipamentos e projetos que recuperariam a memória do desenvolvimento científico e tecnológico do Estado e, também, com um espaço de cultura, com cinema, teatro, biblioteca, laboratórios de criação (laboratórios hacker e fablabs), para que a juventude possa, pondo a mão na massa, inventar e criar e, com isso, contribuir com a construção do nosso presente e do nosso futuro.

Versão reduzida publicada no jornal A Tarde, Salvador, em 9 de março de 2015.

\section{A Bahia na SBPC}

Em 1981, a reunião anual da Sociedade Brasileira para o Progresso da Ciência, a SBPC, foi aqui em Salvador e o circo foi instalado. Era secretária regional a professora Maria de Azevedo Brandão e estávamos juntos para 